\title{
U-2012: An improved Lowry protein assay, insensitive to sample color, offering reagent stability and enhanced sensitivity
}

\author{
Girish C. Upreti ${ }^{1}$, Yanming Wang ${ }^{1}$, Alona Finn ${ }^{1}$, Abigail Sharrock ${ }^{1,2}$, Nicholas Feisst ${ }^{1}$, Marcus Davy ${ }^{1}$, and Robert B. \\ Jordan $^{1}$ \\ ${ }^{1}$ Plant \& Food Research Ruakura, Private Bag 3230, Hamilton, 3240, New Zealand, ${ }^{2}$ University of Waikato, Private Bag \\ 3105, Hamilton, New Zealand
}

Traditional colorimetric protein assays such as Biuret, Lowry, and modified Lowry (U-1988) are unsuitable for colored biological samples. Here we describe an improved Lowry protein assay (U-2012), which utilizes stable reagents and offers enhanced sensitivity over the U-1988 assay. U-2012 circumvents interference from colored pigments and other substances (for example sugars) bound to perchloric acid (PCA) precipitated proteins by hydrogen peroxide $\left(\mathrm{H}_{2} \mathrm{O}_{2}\right)$ induced oxidation at $50^{\circ} \mathrm{C}$. Unused hydrogen peroxide is neutralized with sodium pyruvate before protein estimation for a stable end color. The U-2012 assay is carried out on the PCA precipitated protein pellet after neutralization (with $\mathrm{Na}_{2} \mathrm{CO}_{3}$ plus $\mathrm{NaOH}$ ), solubilization (in Triton- $\mathrm{NaCl}$ ), decolorization $\left(\right.$ by $_{2} \mathrm{O}_{2}$ ) and pyruvate treatment. Protein contents in red wine and homogenates of beetroot and blueberry are calculated from standard curves established for various proteins and generated using a rectangular hyperbola with parameters estimated with Microsoft Excel's Solver add-in. The U-2012 protein assay represents an improvement over U-1988 and gives a more accurate estimation of protein content.

Quantitative measures of physiological traits such as enzyme activity are often expressed as units of activity per milligram protein. Although numerous assays have been developed to measure protein content, including the colorimetric assays of Amido Black (1), Biuret (2), Bicinchoninic Acid (3) and Coomassie Blue $(4,5)$, the Lowry assay $(6)$ or its modifications $(7,8)$ are more commonly used than other assays (9). The Lowry assay is simple, sensitive and precise, and is the most cited (10) procedure for quantitative protein determination.

A wide variety of compounds that react with Folin-Ciocalteu phenol (Folin's) reagent (11) are a source of potential interference in Lowry and modified Lowry protein assays. Fortunately, corrections through an appropriate blank is sufficient for most compounds $(6,7)$ except lipids (12), detergents (13) and colored substances (14). Difficulties in assaying proteins in presence of lipids and detergents (used in the solubilization of adipose tissue, myelin and skeletal muscles) were overcome by the modified Lowry assay (15; referred to in this paper as the U-1988 assay, 16). Color interference in determining the protein content in red wine $(14,17,18)$ was overcome by employing extensive chromatography. The above approach is cumbersome and not very practical for handling large numbers of samples. None of the known protein assays were suitable for measuring proteins in colored biological samples e.g., colored fruits and vegetables, red wine, pigmented microbes and ruminant bile.

Our development of the U-2012 assay from its predecessors the U-1988 and the Lowry assay has achieved three major advantages $(i)$ convenience through stability of the reagent formulations, (ii) measurement of protein in both colorless and colored biological samples without compromising the sensitivity, and (iii) assaying proteins at very low concentrations. This novel assay will be applicable to quantitative determination of protein in both colorless and colored biological sample homogenates, including those rich in lipids (e.g., avocado) and those difficult to homogenize.

\section{Materials and methods}

Biological samples - beetroot,

blueberry and red wine

Beetroot and blueberry homogenates were prepared as described in the Supplementary Material. Red wine did not require protein extraction prior to the U-2012 assay.

Chemical reagents

All chemical reagents, except sodium hypochlorite and perchloric acid (PCA), were obtained from Sigma or Sigma-Aldrich (St Louis, MO. USA). Sodium hypochlorite was from Acros Organic, New Jersey, USA. PCA was obtained from $\mathrm{BDH}$ (England).

Improvements to U-1988 assay

Switching from carbonate to phosphate buffer at $\mathrm{pH} 12.0$ improved reagent stability and gave a small increase in sensitivity. Acetonitrile was 
introduced to avoid detergent-induced bubbles. $\mathrm{NaOH}$ replaced $\mathrm{KOH}$ to avoid precipitation in the protein assay. In addition, efficiency was enhanced by combining various components of the Lowry reagent into one reagent mix.

\section{The U-2012 assay}

Full details of the U-2012 assay are provided in Supplementary Material. The protocol, briefly summarized in Figure 1, describes the processing of red wine and the homogenates of beetroot and blueberry, and includes the improvements to the U-1988 assay. The U-2012 assay was employed for unprocessed, processed [treated with either trichloroacetic acid (TCA) or PCA followed by hydrogen peroxide $\left.\left(\mathrm{H}_{2} \mathrm{O}_{2}\right)\right]$ and reverse processed $\left(\mathrm{H}_{2} \mathrm{O}_{2}\right.$ treatment followed by TCA or PCA precipitation) proteins. Assays were carried out on BSA, carbonic anhydrase, cytochrome C, isocitrate dehydrogenase, lysozyme and trypsin for the development of standard curves and in colored biological samples. The determination of proteins in the biological samples was carried out by calibrating to appropriate standard curves.

\section{Estimation of color interferences}

in the U-2012 assay

Color interference was determined by comparing absorbency from processed and unprocessed beetroot, blueberry and red wine samples both with and without the use of Folin's reagent as described in Figure 1. The ratio $[(A b s 1-A b s 2) /(A b s 3-A b s 4)]$ was used to establish the extent of interference, where Abs1 is absorbance of unprocessed samples with Folin's reagent; Abs 2 is absorbance of unprocessed samples without Folin's reagent; Abs3 is absorbance of processed samples with Folin's reagent; and Abs 4 is absorbance of processed samples without Folin's reagent.

The standard curve and its parameters Solution-1B and $1 \mathrm{C}$ described in the Recipes section of the attached Supplementary Material were used for the development of the standard curves. The concentration of BSA and the corresponding absorbance values were plotted using an X-Y scatter graph. The form of this graph (Figure 2) shows a saturating response at higher concentrations with a very limited initial linear response. This was a preferred curve form reported previously (20). Initially this was modeled using an exponential form (19) but later studies showed that a rectangular hyperbola gave an improved alignment with the response, particularly at lower concentrations. This latter form has now been standardized and the following three-parameter equation was used to describe the absorbance-protein concentration relationship:

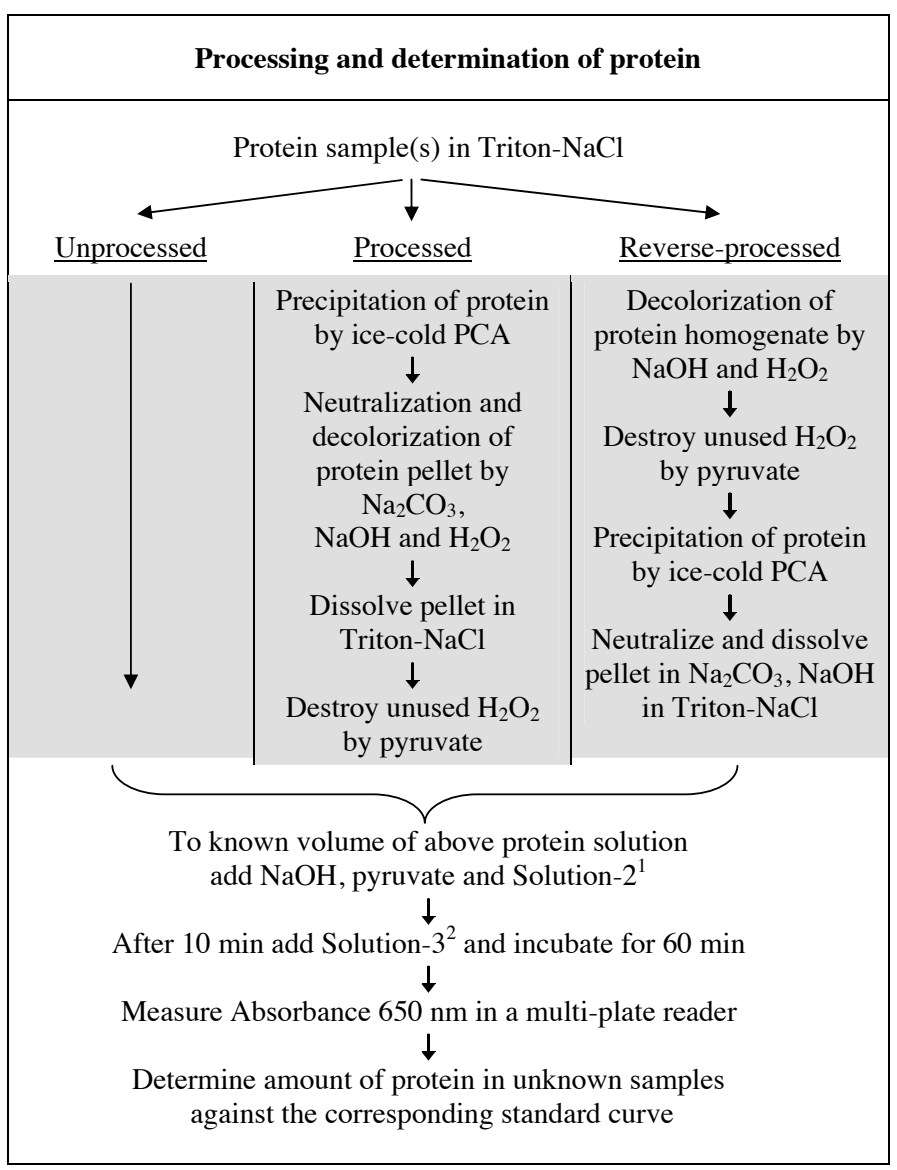

Figure 1. Procedure for the U-2012 assay. ${ }^{1}$ Solution-2 contained copper sulfate $\left(\mathrm{CuSO}_{4} \cdot 5 \mathrm{H}_{2} \mathrm{O}\right)$, Na-KTartrate, SDS and acetonitrile in 100 mM phosphate buffer (pH 12.0). '²or Solution-3, Folin-Ciocalteu's phenol reagent was diluted 1:1 with deionized water just before use.

$$
A=A_{0}+\frac{\left(A_{M}-A_{0}\right) \text { Conc }}{\left(C_{50}+\text { Conc }\right)} \text { [Eq. 1] }
$$

Conc $=$ Protein concentration,

$\mathrm{A}=$ Absorbance at Conc,

$\mathrm{A}_{0}=$ Absorbance at zero concentration,

$\mathrm{A}_{\mathrm{M}}=$ Absorbance at max concentration,

$\mathrm{C}_{50}=$ Concentration giving absorbance

$\left(\mathrm{A}_{\mathrm{M}}+\mathrm{A}_{0}\right) / 2$.

Parameter $\mathrm{A}_{0}$ was experimentally determined while $A_{M}$ and $C_{50}$ were estimated using Microsoft Excel's Toolbox add-in Solver Function. A trial set of parameters was used to calculate the modeled absorbance at each of the standard concentrations (Conc) using equation [1]. Solver was then commanded to minimize the residual standard deviation between the measured and modeled absorbance for the standard set by adjusting $\mathrm{A}_{\mathrm{M}}$ and $\mathrm{C}_{50^{\circ}}$.

We observed the relationship between absorbance and concentration to exhibit a non linear curve over the entire concentration range, which is likely to be due to a component of light scattering which increases as the concentration of protein increases when measuring absorbance. A poor linear fit at low absorbance was also reported by Coakley and James (20).

\section{Calculation of protein content in} the homogenates

Assays were carried out on processed and unprocessed red wine and homogenates of beetroot and blueberry. BSA and other protein samples were treated identically for appropriate standard curves to determine $\mathrm{A}_{0}, \mathrm{~A}_{\mathrm{M}}$ and $\mathrm{C}_{50}$ values. These parameters were then used to convert sample absorbance (A) to protein concentration in each homogenate using:

$$
\text { Conc }=\frac{C_{50}\left(A-A_{0}\right)}{\left(A_{M}-A\right)} \text {. }
$$

Because the equation has a saturating form, the sensitivity reduces as absorbance $(\AA)$, and hence concentration, increases. Errors in protein estimations may be minimized by adjusting the concentrations of homogenates in the assay so that they do not excessively exceed the $\mathrm{C}_{50}$ value.

The Homogenate Conc value was then converted to tissue protein concentration 
(Tissue Conc in mg/g of tissue) using the following formula:

Tissue Conc $=$ Homogenate Conc $\times 100 /$ Homogenate percentage

[Eq. 3]

where Homogenate Conc (in mg protein $/ \mathrm{mL}$ ) has been corrected for any pre-concentration or dilution during the assay. Homogenate percentage was $100 \mathrm{~g}$ of tissue homogenized to a total volume of $200 \mathrm{~mL}$ (in our case $50 \%$ ).

In a separate study, a rectangular hyperbola model was fitted using the non linear mixed effects (NLME) package (21) in $\mathrm{R}$ (22) (Figure 2). Each BSA solution, made independently in the laboratory, was modeled as a random effect, with a common $\mathrm{A}_{0}$ but different $\mathrm{A}_{\mathrm{M}}$ and $\mathrm{C}_{50}$ coefficients. This models the hierarchy of biological sample replicates and technical assay replicates.

\section{Results and discussion}

Improvements in the U-1988 assay

The limitation of the U-1988 and the Lowry assay is the instability of the carbonate-based reagent. The carbonate buffer $(\mathrm{pH} 11.4$ at $2 \%$ $=188.7 \mathrm{mM}$ ) in U-1988 was replaced with $40 \mathrm{mM}$ phosphate at $\mathrm{pH}$ values ranging from 11.4 to 12.5. Initial slopes from the standard curves of the protein assay using BSA at $0.5 \mathrm{mg}$ $\mathrm{BSA} / \mathrm{mL}$ and $1.0 \mathrm{mg} \mathrm{BSA} / \mathrm{mL}$ were calculated. The initial slopes with phosphate buffers at $\mathrm{pH} 11.4$ and at its optimal $\mathrm{pH} 12.0$ were 99 $\times 10^{-6}$ and $197 \times 10^{-6}$ respectively. The slope for the carbonate buffer ( $\mathrm{pH} 11.4$ ) was $162 \times 10^{-6}$.

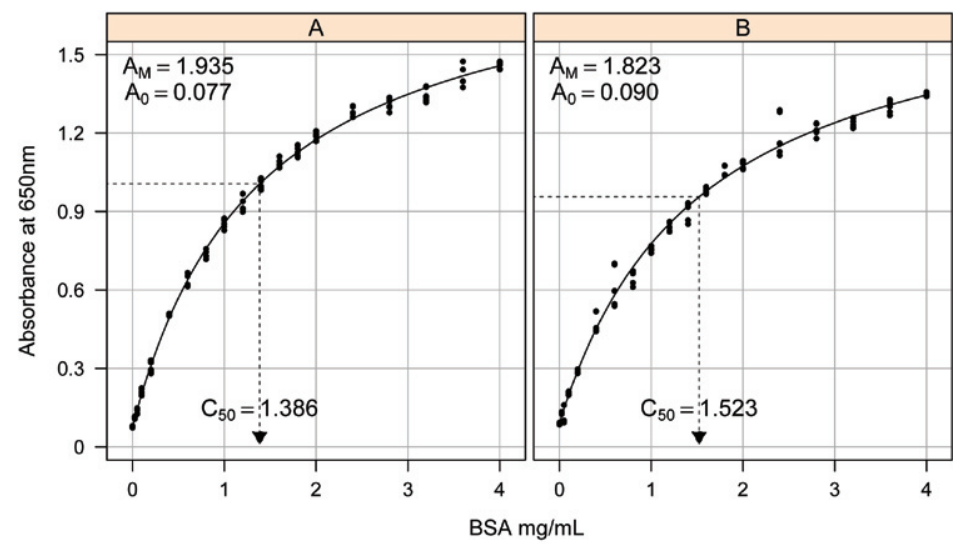

Figure 2. Standard curve for protein assay. Estimation of the standard curve between the absorbance $(650 \mathrm{~nm})$ and concentrations of BSA protein was made on three technical replicates to $(A)$ the unprocessed protein assay (parameters $A_{0}=0.077, A_{m}=1.935, C_{50}=1.386$ ), and $(B)$ the processed protein assay (parameters $A_{0}=0.90, A_{m}=1.823, C_{50}=1.523$ ). A rectangular hyperbola model (equation [1]) was fitted to the observed data. Parameter estimates are identified in the curves with the $\mathrm{C}_{50}$ estimation on the $x$-axis (dotted black line).

Since the slope value is a direct indication of assay sensitivity, phosphate buffer ( $\mathrm{pH} 12.0)$ was chosen to replace carbonate buffer, giving a $25 \%$ increase in sensitivity.

Greater stability was achieved by increasing concentration of the phosphate buffer to 100 $\mathrm{mM}$. The resulting phosphate $/ \mathrm{CuSO}_{4} / \mathrm{Na}-\mathrm{K}-$ tartrate solution was stable at room temperature for two weeks, considerably longer than the carbonate $/ \mathrm{CuSO}_{4} / \mathrm{Na}-\mathrm{K}$-tartrate solution, which must be prepared daily before protein assay. For all future experiments, $100 \mathrm{mM}$ phosphate ( $\mathrm{pH} 12.0)$ was used to prepare the $\mathrm{CuSO}_{4} / \mathrm{Na}-\mathrm{K}$-tartrate solution. We believe that replacement of carbonate with phosphate will enhance the convenience of the U-2012 assay.
Detergent induced bubbles become a major source of error in absorbance measurements when using a multi-well plate reader (not an issue with cuvettes). These bubbles were reduced considerably by the addition of a number of polar solvents (e.g., acetone, acetonitrile, ethanol and methanol). Acetonitrile, the most polar of these solvents (23) was chosen for its effectiveness and included in Solution-2 (see Figure 1 caption and Recipes section of Supplementary Material).

Phosphate buffer, $\mathrm{CuSO}_{4}$, Na-K-tartrate, SDS and acetonitrile can be added individually and the order of their addition does not affect the resulting absorbance. However, using

Table 1: Three point parameters of various protein standard curves.

\begin{tabular}{|c|c|c|c|c|c|c|c|}
\hline \multirow{2}{*}{ Protein } & \multirow{2}{*}{ Treatment } & \multirow{2}{*}{$\mathbf{N}^{1}$} & \multicolumn{3}{|c|}{ Three parameters from standard curve ${ }^{2}$} & \multirow{2}{*}{ RSE $^{3}$} & \multirow{2}{*}{ Conc at $A=1.0$} \\
\hline & & & $A_{0}$ & $A_{M}$ & $C_{50}$ & & \\
\hline \multirow{3}{*}{ BSA } & Unprocessed ${ }^{4}$ & 106 & 0.077 & 1.935 & 1.386 & 0.020 & 1.368 \\
\hline & Processed ${ }^{4,5}$ & 112 & 0.090 & 1.823 & 1.523 & 0.033 & 1.684 \\
\hline & Reverse-processed ${ }^{5}$ & 106 & 0.108 & 1.844 & 2.024 & 0.025 & 2.140 \\
\hline \multirow{3}{*}{ Trypsin } & Unprocessed & 34 & 0.074 & 2.016 & 0.770 & 0.042 & 0.702 \\
\hline & Processed & 76 & 0.110 & 2.078 & 1.093 & 0.043 & 0.902 \\
\hline & Reverse-processed & 114 & 0.096 & 1.432 & 5.302 & 0.012 & 11.092 \\
\hline \multirow{2}{*}{ Lysozyme } & Unprocessed & 76 & 0.087 & 1.911 & 0.846 & 0.048 & 0.848 \\
\hline & Processed & 76 & 0.106 & 1.719 & 0.682 & 0.048 & 0.849 \\
\hline $\begin{array}{c}\text { Isocitrate } \\
\text { dehydrogenase }\end{array}$ & Processed & 16 & 0.085 & 1.682 & 2.012 & 0.014 & 2.701 \\
\hline $\begin{array}{c}\text { Carbonic } \\
\text { anhydrase }\end{array}$ & Processed & 16 & 0.076 & 1.689 & 1.396 & 0.011 & 1.872 \\
\hline Cytochrome C & Processed & 12 & 0.086 & 1.501 & 1.346 & 0.019 & 2.457 \\
\hline Average $( \pm$ SEM) & For all processed proteins & - & $\begin{array}{c}0.092 \\
( \pm 0.005)\end{array}$ & $\begin{array}{c}1.749 \\
( \pm 0.078)\end{array}$ & $\begin{array}{c}1.342 \\
( \pm 0.181)\end{array}$ & - & 1.744 \\
\hline
\end{tabular}


a premixed solution further enhances convenience, especially when large numbers of samples are to be assayed. We therefore grouped these components of the assay mix into Solution-2 (Figure 1). Such a premixed solution was not feasible for the original Lowry assay (6) due to instability of the carbonate solution. The attempt to include Solution-3 in Solution-2 resulted in dramatic reduction in the development of blue color and was not considered further.

Protein estimation in colored

biological samples

Protein extraction

Proteins from beetroot and blueberry were extracted in Triton $\mathrm{X}-100-\mathrm{NaCl}$ solution with mild homogenization. Such homogenates retain their enzyme activities (15). This extraction was not required for red wine.

\section{Eliminate interfering substances}

For colored samples it is necessary to remove the interference due to the inherent sample color and other non-protein substances that react with the protein reagents before colorimetric protein assay. The novelty of U-2012 is in devising a decolorizing protocol compatible with a colorimetric protein assay.
Decolorization of colored pigments by sodium hypochlorite or $\mathrm{H}_{2} \mathrm{O}_{2}$ and selective precipitation of proteins by PCA or TCA were considered for removal of interfering substances. Sodium hypochlorite, $\mathrm{H}_{2} \mathrm{O}_{2}$, TCA and PCA were evaluated for their compatibility with the U-2012 assay using BSA as the test protein. Between sodium hypochlorite and $\mathrm{H}_{2} \mathrm{O}_{2}$, only $\mathrm{H}_{2} \mathrm{O}_{2}$ was compatible as a precipitate was formed in the presence of hypochlorite. Proteins precipitated by TCA or PCA can be assayed by U-2012 after adequate neutralization of residual acid in the pellet. The superiority of PCA over TCA for protein precipitation has been reported (24, $25)$. In contrast, in our comparative evaluation, revealed similar $\mathrm{C}_{50}$ values for PCA (1.395) and TCA (1.400). We preferred PCA because it is readily available as a pre-made solution $(70 \%$ $\mathrm{v} / \mathrm{v}$ ) and therefore easily diluted to the required strength. TCA is a hygroscopic solid that is difficult to weigh precisely due to its variable water content.

There are two possible ways of combining PCA and $\mathrm{H}_{2} \mathrm{O}_{2}$. For "processed" proteins PCA treatment was followed by $\mathrm{H}_{2} \mathrm{O}_{2}$ treatment and for "reverse-processed" protein, $\mathrm{H}_{2} \mathrm{O}_{2}$ treatment preceded PCA precipitation. Advan- tages of using 'processed' protein were the removal of a number of interfering substances in the supernatant and the possible inactivation of proteolytic enzymes during sample preparation. This was confirmed by assaying processed and reverse-processed trypsin and BSA (see Table 1). Only processed samples were used to determine the actual protein content of colored biological samples

Both PCA and $\mathrm{H}_{2} \mathrm{O}_{2}$ treatments of colored samples were necessary for interference elimination in U-2012 assay. Acid precipitation alone of the colored samples did not remove interference completely. With all the colored samples, some color was discarded in the supernatant, but the pellets were also colored. Color was eliminated from the pellets by $\mathrm{H}_{2} \mathrm{O}_{2}$ treatment. Alkaline conditions were required for both effective decolorization by $\mathrm{H}_{2} \mathrm{O}_{2}$ (26) and the color development by Folin's reagent to ensure that protein levels are measured correctly. Although both $\mathrm{NaOH}$ and $\mathrm{KOH}$ could provide the required alkalinity, only $\mathrm{NaOH}$ was compatible with the U-2012 assay. A precipitate was formed in the presence of $\mathrm{KOH}$. In pellets, the PCA was neutralized using $\mathrm{Na}_{2} \mathrm{CO}_{3}$ and $\mathrm{NaOH}$ (27). Additional $\mathrm{NaOH}$ was added during the assay; the optimized volume was between 50 to $70 \mu \mathrm{L}$ $(60 \mu \mathrm{L}$ was routinely used); see Figure 1.

Beetroot, blueberry, and red wine were decolorized with $15 \mu \mathrm{L}$ of $30 \% \mathrm{H}_{2} \mathrm{O}_{2}$ taking 0.5 and $2 \mathrm{~h}$ at $50^{\circ} \mathrm{C}$ and room temperature, respectively. Twenty microliters of $30 \% \mathrm{H}_{2} \mathrm{O}_{2}$ for $1 \mathrm{~h}$ at $50^{\circ} \mathrm{C}$ was used to cope with stronger colored samples. Oxidation of substances like sugars bound to proteins by $\mathrm{H}_{2} \mathrm{O}_{2}$ at $50^{\circ} \mathrm{C}$ seems critical as room temperature processing overestimates protein content. In the case of beetroot, $50^{\circ} \mathrm{C}$ processing reduced the apparent protein estimate to $14 \%$ of the unprocessed, whereas room temperature processing only halved that estimate.

It was evident from the colorimetric assays carried out after hydrogen peroxide treatment that some $\mathrm{H}_{2} \mathrm{O}_{2}$ was not utilized in the decolorization. In such a sample, the end color of the Lowry assay was partially destroyed. It was therefore necessary to destroy the remaining hydrogen peroxide before protein assay. There are two sources of $\mathrm{H}_{2} \mathrm{O}_{2}$ in the U-2012 assay; $\mathrm{H}_{2} \mathrm{O}_{2}$ added for decolorization and $\mathrm{H}_{2} \mathrm{O}_{2}$ present as a contaminant in the Triton X-100 (0.22\%, Product information: Triton X-100, www.sigmaaldrich.com). Hydrogen peroxide is commonly degraded by the enzyme catalase. However, the high $\mathrm{pH}$ of the protein assay would inactivate known catalases. Also, adding catalase would lead to the addition of extra protein. We chose chemical destruction of $\mathrm{H}_{2} \mathrm{O}_{2}$ using pyruvate (28). The chemistry of the pyruvate- $\mathrm{H}_{2} \mathrm{O}_{2}$ interaction equation [4] is well established $(28,29)$. Pyruvate destroys $\mathrm{H}_{2} \mathrm{O}_{2}$ at room temperature according to the following reaction: 
the standards using simple procedures within Microsoft Excel.

\section{IN PIPEIIES}

The BRAND Transfenpette ${ }^{\oplus} \mathcal{S}$

The BRAND

Transferpette ${ }^{\circledR} \mathcal{S}$

pipettes offer an array

of performance and

convenience features

never before combined

in a single pipette.

- Simple, one-thumb

volume

adjustment

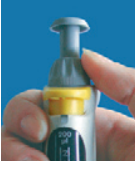

- "No-stretch" pipette button: shortest stroke length among leading pipettes

- Covered I.D. label

- Easy dissassembly for cleaning

- Built-in calibration without tools

- Completely autoclavable

\section{- Special Promo}

Buy 2, get 1 FREE!

Buy from preferred dealers.

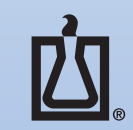

BRAND

Visit www.brandtech.com for promo details.

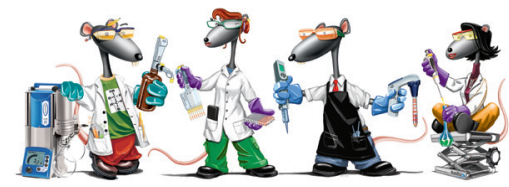

Lab Rats Trust BrandTech ${ }^{\circledR !}$

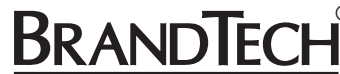
SCIENTIFIC, INC.

\section{Acknowledgments}

Authors acknowledge the Foundation for Research, Science and Technology New Zealand for financial support (C06X0809).

\section{Competing interests}

The authors declare no competing interests.

\section{References}

1. Kaplan, R.S. and P.L. Pedersen. 1985. Determination of microgram quantities of protein in the presence of milligram levels of lipid with amido black 10B. Anal. Biochem.150:97-104.

2. Gornall, A.G., C.J. Bardawill, and M.M. David. 1949. Determination of serum proteins by means of the biuret reaction. J. Biol. Chem. 177:751766.

3. Smith, P.K., R.I. Krohn, G.T. Hermanson, A.K. Mallia, F.H. Gartner, M.D. Provenzano, E.K. Fujimoto, N.M. Goeke, et al. 1985. Measurement of protein using bicinchoninic acid. Anal. Biochem. 150:76-85.

4. Bradford, M.M. 1976. A rapid and sensitive method for the quantification of microgram quantities of protein utilizing the principle of protein-dye binding. Anal. Biochem. 72:248-254.

5. Zor, T. and Z. Selinger. 1996. Linearization of the Bradford protein assay increases its sensitivity: theoretical and experimental studies. Anal. Biochem. 236:302-308.

6. Lowry, O.H., N.J. Rosbrough, A.L. Farr, and R.J. Randall. 1951. Protein measurement with the Folin phenol reagent. J. Biol. Chem. 193:265-275.

7. Peterson, G.L. 1979. Review of the folin phenol protein quantification method of Lowry, Rosebrough, Farr and Randall. Anal. Biochem. 100:201-220.

8. Sapan, C.V., R.L. Lundablad, and N.C. Price. 1999. Colorimetric protein assay techniques. Biotechnol. Appl. Biochem. 29:99-108.

9. Okutucu, B., A. Dınçer, Ö. Habib, and F.Zıhnıoglu. 2007. Comparison of five methods for determination of total plasma protein concentration. J. Biochem. Biophys. Methods 70:709-711. The most highly cited paper in publishing history: protein determination by Oliver H. Lowry.J. Biol. Chem. 25:280

11. Everette, J.D., Q.M. Bryant, A.M. Green, Y.A. Abbey, G.W. Wangila, and R.B. Walker. 2010. Thorough study of reactivity of various compound classes toward the Folin-Ciocalteu Reagent. J. Agric. Food Chem. 58:8139-8144.

12. Eichberg, J. and L.C. Mokrasch. 1969. Interference by oxidized lipids in the determination of protein by the Lowry procedure. Anal. Biochem. 30:386-390.

13. Dulley, J.R. and P.A. Grieve. 1975. A simple technique for eliminating interference by detergents in the Lowry method of protein determination. Anal. Biochem. 64:136-141.

14. Brillouet, J.-M., M.-P. Belleville, and M. Moutounet. 1991. Possible protein-polysac42:150-152.

15. Upreti, G.C., R.A. Ratcliff, and P.C. Riches. 1988. Protein estimation in tissues containing high levels
10. Kresge, N., R.D. Simoni, and R.L. Hill. 2005. charide complexes in red wines. Am.J. Enol. Vitic. oflipid: modifications to Lowry method of protein determination. Anal. Biochem. 168:421-427.

16. Upreti, G.C., C. Davis, and J. Oliver. 1991. Preparation of representative homogenates of biological tissues: effect of salt on protein extraction. Anal. Biochem. 198:298-301.

17. Smith, M.R., M.H. Penner, S.E. Bennett, and A.T. Bakalinsky. 2011. Quantitative Colorimetric Assay for Total Protein Applied to the Red Wine Pinot Noir. J. Agric. Food Chem. 59:6871-6876.

18. Wigand, P., S. Tenzer, H. Schild, and H. Decker. 2009. Analysis of Protein Composition of Red Wine in Comparison with Rosé and White Wines by Electrophoresis and High-Pressure Liquid Chromatography-Mass Spectrometry (HPLCMS). J. Agric. Food Chem. 57:4328-4333.

19. Upreti, G.C., Y. Wang, A. Sharrock, N. Feisst, M. Davy, and B. Jordan. 2009. A stable and sensitive protein assay (U-2009 modified assay) for colored biological samples. ComBiol., New Zealand Final Programme December 2009, University of Canterbury, Christchurch, New Zealand.

20. Coakley, W.T. and C.J. James. 1978. A simple linear transform for the Folin-Lowry protein calibration curve to $1.0 \mathrm{mg} / \mathrm{mL}$. Anal. Biochem. 85:90-97.

21. Pinheiro, J.C. and D.M. Bates. 2000. MixedEffects Models in S and S-PLUS, Statistics and Computing Series, Springer-Verlag, New York, NY.

22. R Development Core Team. 2009. R: A language and environment for statistical computing. $\mathrm{R}$ Foundation for Statistical Computing, Vienna, Austria, ISBN 3-900051-07-0, URL http:// www.R-project.org.

23. Khachik, F., G.R. Beecher, J.T. Vanderslice, and G. Furrow. 1988. Liquid chromatographic artifacts and peak distortion: Sample-solvent interaction in the separation of carotenoides. Anal. Chem. 60:807-811.

24. Cernik, A.A. 1970. Determination of lead chelated with ethylenediaminetetra-acetic acid in blood after precipitation of protein with perchloric acid. Brit. J. Industry Med. 27:40-42.

25. Moughan, P.J., A.J. Darragh, W.C. Smith, and C.A. Butts. 1990. Perchloric and trichloroacetic acids as precipitants of protein in endogenous ileal digesta from the rat. J. Sci. Food Agric. 52:13-21.

26. Galbács, Z.M. and L.J. Csányi. 1983. Alkaliinduced decomposition of hydrogen peroxide. J. Chem. Soc., Dalton Trans. (11):2353-2357.

27. Scopes, R.K. 1988. Protein Purification: Principles and Practice, Second Ed., Springer-Verlag New York Inc., New York, NY.

28. Upreti, G.C., K. Jensen, R. Munday, D.M. Duganzich, R. Vishwanath, and J.F. Smith. 1998. Studies on aromatic amino acid oxidase activity in ram spermatozoa: role of pyruvate as an antioxidant. Anim. Reprod. Sci. 51:275-287.

29. Holleman, M.A.F. 1904. Notice sur l'action de l'eau oxygenee sur les acids $\alpha$-cetoniques et sur les dicetones 1.2. Recl. Trav. Chim. Pays-Bas Belg. 23:169-172.

Received 28 June 2011; accepted 17 January 2012.

Address correspondence to Girish Upreti, Plant \& Food Research Ruakura, Private Bag 3230, Hamilton, 3240, New Zealand. Email: girish.upreti@plantandfood.co.nz

To purchase reprints of this article, contact: biotechniques@fosterprinting.com 